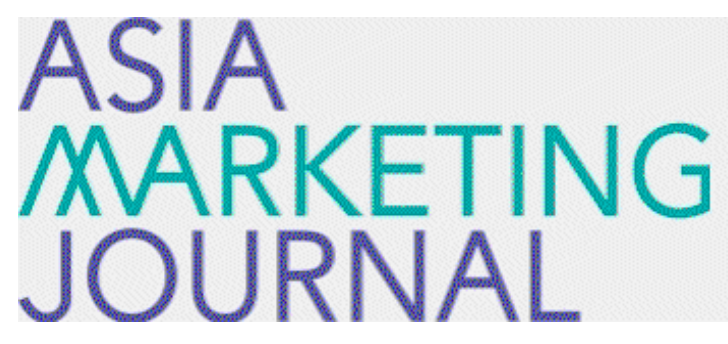

ASIA MARKETING JOURNAL

Volume 19 | Issue 4

Article 2

$1-31-2018$

\title{
Consumer Value and Social Media Usage on Luxury Product for Vietnamese Consumers
}

Hyowon Hyun

JungKun Park

Tuan Ba Pham

Ren

Follow this and additional works at: https://amj.kma.re.kr/journal

Part of the Marketing Commons

\section{Recommended Citation}

Hyun, Hyowon; Park, JungKun; Pham, Tuan Ba; and Ren (2018) "Consumer Value and Social Media Usage on Luxury Product for Vietnamese Consumers," Asia Marketing Journal: Vol. 19 : Iss. 4 , Article 2.

Available at: https://doi.org/10.15830/amj.2018.19.4.15

This Article is brought to you for free and open access by Asia Marketing Journal. It has been accepted for inclusion in Asia Marketing Journal by an authorized editor of Asia Marketing Journal. 


\title{
Consumer Value and Social Media Usage on Luxury Product for Vietnamese Consumers
}

\author{
Hyowon Hyun* \\ JungKun Park** \\ Tuan Ba Pham*** \\ Tianbao Ren****
}

\begin{abstract}
Vietnamese luxury market is rapidly growing, however, there is a few researches on Vietnamese consumers' perceptions of luxury products and influential factors in purchasing intention. The purpose of this study is to explore Vietnamese consumers' value dimensions and mediating effect of social media information for their decision making for luxury product. Data were collected using self-administered mail survey. This study examines the influences of consumers' perceptions of quality and value, and social media word-of-mouth on Vietnamese consumers' luxury purchase intention.
\end{abstract}

Key words: Luxury product, social media, perceived quality, value dimensions, Vietnamese Consumers

\section{Introduction}

Demands of luxury products, a concept of refined enjoyment, elegance, and desirable but not essential (Goody 2006), are attracting more and more consumers all over the world and Vietnamese market is no exception. In addition to owning the expensive luxury items, the consumers are given the satisfaction of the extra-added psychological benefits like elevated self-esteem, prestige, and a sense of a high status by the attributes of luxury products/ services. Thus, despite the recession global economic, luxury market is still projected to continue growing at a steady rate of $2-3 \%$,

\footnotetext{
* Doctoral Student, Business school of Hanyang University, Korea (hhwony326@gmail.com)

** Professor, Business school of Hanyang University, Korea (viroid2007@gmail.com), Corresponding Author

*** Doctoral Student, Global Retailing at University of Houston, USA (tbpham@uh.edu)

**** Doctoral Student, Business school of Hanyang University, Korea (rtb630678601@gmail.com)
} 
reaching an estimated $€ 280-295$ billion in revenue (Kim and Wingate 2017). The considerable growth of the luxury-goods market has mainly been boosted by emerging Asian economies where middle classes with increasing disposable income are rising dramatically (Gorrab 2013; Neate 2013). Vietnam is one of the most attractive market in Asian with the economic growth of middle class. The middle class, who will use $18 \%$ of their monthly income, will be tripled in Vietnam (Lee and Nguyen 2017). Moreover, following with increasing of household income level (Truc, Thanh, Nguyen and Jan 2016), for foreign retailers Vietnam is a fascinating marketing with a high population base and high growth rate of population. In addition, some foreign brands such as from Europe, U.S., Japan and South Korea are take intense competition in Vietnam (Lee and Nguyen 2017). Vietnam retail market's growth has driven by increasing demand of consumer goods and rising disposable incomes. Expanded urbanization and increased rural retail areas in recent years which promoted by improved infrastructure will be making easier such growth of luxury market. Associated with rapid economic development and increased education, the next-generation Vietnamese consumers who are markedly different from their predecessors in terms of information have more information about products and markets, and therefore more sophisticated needs of quality and value products. With the perception of luxury products as the driving factor in the tangibalization of success (Lee 2012), middle and upper classes' willingness to pay a large amount of money for luxury product (D'arpizio, Levato, Zito and de Montgolfier 2014), Vietnam retail market has been the land of promise for luxury products besides the new fascinating luxury markets such as Russia, Brazil, China, etc. (Diniz 2014). However, the factors influencing on purchase intentions for luxury products in Vietnam is limited despite its necessaries for marketing strategies for global luxury brands.

According to report on social media marketing published by Sashi (2012), major Vietnamese market research company, social media has been an important channel of customer care in Vietnam. More and more customers use social media as a channel to interact with companies, including questioning, commenting, reviewing products/services, getting advices as well. Moreover, about half of respondents agree that they are impacted by "advertising" posted by people in their friend lists or people they are following. Previous study around luxury fashion brand showed that social medial is dramatic impact on brand equity especially in consumers' purchase intention (Kim and Ko 2012). To authors' knowledge, until now there are no academic research on factors affecting the social media word-of-mouth as well as its effects on purchase intentions, especially luxury industry in Viet Nam. By examining Vietnamese consumers' perception of quality on luxury products, which 
impact on purchase intentions for luxury product and social media word-of-mouth, this study will research the literature of Vietnamese consumer behavior towards purchasing luxury product due to socioeconomic changes. This study will explode whether luxury retailers can strongly appeal to the consumers' purchase motivations in their marketing campaigns, by understanding Vietnamese consumers' perceptions and factors influencing purchase intentions for luxury products.

\section{Theoretical Background}

For the majority, consumer perceived value has been the great interest for consumer behavioral researchers and marketers, and it has been playing an important role in the survival of organizations and businesses. However, there was no consensus to define consumer's perceived values. Moreover, only customers can realize the value of the offered products or services (Teas and Agarwal 2000). There are two different approaches to the consumers' perceived value. Firstly, perceived value is a construct including benefits received (i.e., economic, social, and relational) and sacrifices made (i.e., price, time, effort, risk, and convenience) by consumers (Cronin, Michael, Hult 2000). According to another major approach, the perceived value is identified as a multidimensional construct (Sweeney and Soutar 2001).

Focusing on value of luxury product, Vigneron and Johnson (2004) developed two distinct dimensions of luxury product value perceptions, namely personal perceptions and non-personal perceptions. Wiedmann, Nadine and Astrid (2007) conceptualized that luxury products have four latent value dimensions: social, individual, functional, and financial. Shukla (2011) proposed a brand luxury index by classifying three major dimensions of luxury value perceptions: social value perceptions including conspicuous value and status value, personal value perceptions including hedonism and materialism, and functional value perceptions including uniqueness and price-quality perceptions. Under the impact of the same stimulus (i.e. new product, advertising, and promotion program), consumers from different cultures have different perceptions, attitudes, and behaviors towards the products (McCracken 1990). Indeed, consumers' perception of value for the purchasing process is principally influenced by cultural dimensions of uncertainty-avoidance and individualismcollectivism (Sabiote, Dolores and Castañeda 2013). Moreover, priority hierarchy of value dimensions is varied from country over other countries. For example, quality value is the most important dimensions for Chinese Generation Y consumers, while emotional value appeared to be the most important dimensions for US Generation Y consumers (Zhao 2006). In fact, there are a sharp differences between developing 
countries such as Vietnamese consumers and others from developed countries. According to Herche (1992), consumers in advanced countries are likely to perceive that domestic products are higher quality than the imported products; whereas, consumers in developing countries, such as Vietnam, tend to be convinced by the fact that the local products are not as good as the imported (Agbonifoh and Elimimian 1999; Nguyen, Trang and Nigel 2008). Thus, based on the preceding research carried out empirical test, this study examines (a) whether the social values, including conspicuous value and status value, influence on consumers' luxury purchase intentions, (b) whether hedonic value has an impact on purchase intentions for luxury products, and (c) whether utilitarian value and luxury purchase intentions have a correlative relationship.

\section{Literature Review}

\subsection{Vietnamese Consumer Research and Market}

Vietnam is at an early stage of retail modernization with development of modern retail outlets, such as hypermarkets, shopping centers, and convenience stores in all major cities. After becoming a member of the WTO in 2007, and latest becoming a member of The
Trans-Pacific Partnership (TPP), which agreement was reached on 5 October 2015 after 7 years of negotiations. Vietnam represents an attractive market for retail investment with a considerable potential. According to Lee and Nguyen (2017), The economy in Vietnam grew 6.5\% with 9.6\% exports increase and $9.8 \%$ of retail sales gain in 2015. In addition, Vietnam retail value sales still shows double digit growth due to continuous urbanization, increasing consumer living standards, and large young population. Thus, foreign retail giants' money is increasingly poured into the retail industry in Vietnam. However, Vietnam retail industry has not received much attention from academics, especially modern retailing.

Vietnamese consumers' living standards have rapidly changed after since policy changes, market reforms, emergence of local entrepreneurs, and multinational corporations' investments (Shultz 1994; Nguyen and Siok 2011). Vietnamese consumers have spent more money to satisfy their growing demands, and their growth of consumption was above $7.4 \%$ in the period from 2001 to 2016. Almost all Vietnamese consumers shop at least five or six times a week (Maruyama and Le 2009). Moreover, consumption patterns of Vietnamese people have changed to spending more and saving less, as well as better quality and high value products. They have reacted positively to modern retailing models (Heath 2000). Vietnamese consumers' expenditure method, especially the new rich, might be impacted by not only 
rationality but also cultural traits, such as their desired image and status. The nature of man is a social creature, so, what others think, feel, and act has a significant effect on Vietnamese consumers. In addition, social media is one of key factors impacting on their behavior. Vietnamese consumer behavior and attitudes are controlled by the belief that they are happier and have higher social status if they buy and use goods which others desire to possess. Many Vietnamese people believe that using luxury products could improve their value, image, and social position. Moreover, the market economy, consumer orientation, and materialistic value are extremely dominant to Vietnamese consumers' perceptions of luxury products, which present their prestige and power.

\subsection{Luxury Brand/product}

What are luxury products? Besanko, Ronald and Gibbs (2011) defines that luxury is personal, relative, and idiosyncratic. In an economics sense, a luxury good, contrast to a necessity good, means an increase of consumption higher than the rate of income (Besanko et al. 2011). Sociological sense, the concept of luxury refers to the social status conferred to an individual who buys and uses by other members of a group (Wegener 1992). According to Veblen (1965), these products are the objects of conspicuous consumption, which satisfy the needs of public display of discretionary economic power rather than their real needs. Price is often used as the measurement of luxury, because high prices often have a positive relationship with the perceived value of product (Vigneron and Johnson 1999).

With unique characteristics of premium quality, a heritage of craftsmanship, recognizable style, premium price, uniqueness, and global reputation, luxury brands provide consumers with a sense of indulgence and are expensive for the individual (Nueno and Quelch 1998). Generally, researchers agree that luxury products have three basic characteristics, including indulgence, expensiveness, and scarceness (Vigneron and Johnson 1999). Consumers buy luxury products primarily for symbolic reasons to reflect their individual or social goals (Wilcox, Hyeong and Sankar 2009). In addition to owning the pricey items, the consumers are given the satisfaction of the extra-added psychological benefits like esteem, prestige, and a sense of a high status by the attributes of luxury products/services. However, concept of luxury is subjective (Phau and Prendergast 2000) is changed across the market segments and time, and depends on consumer's perception of value. Although both western and eastern consumers seek to purchase luxury products in order to express their individuality and exhibit their social standing (Wilcox et al. 2009), motivations for purchasing luxury products are likely to vary by culture (Bian and Forsythe 2012). While consumers in individualist societies 
focus on consciousness, emotional independence, and individual initiative, consumers in collectivist societies tend to share common values and norms such as emotional predispositions, common interests, and mutually agreed upon social practices as well as desire to enhance their self-presentation through purchases of luxury products (Etzioni 1968).

\subsection{Perceived Quality on Luxury Product}

Quality could mean degree of excellence, as in, "a quality product" or "work of average quality”. By extension, perceived quality is defined as the consumers' judgment about the overall superiority or excellence of an entity or a service (Zeithaml 1988). Jin and Suh (2005) insisted that perceived quality is the key factor in the consumer decision, as a result, consumers will compare the quality of alternatives with regards to price within a category. Prestige goods are expected to show evidence of greater quality, and luxury goods should display even greater levels of quality (Garfein 1989). Besides, according to Aaker (1996), perceived quality can deliver value to customers by offering them a purchase reason and by differentiating the product or brand from competitors. Some research revealed the close correlation between luxury consumption and the products' quality. Luxury brands/products are expected to display greater quality (Roux 1995). Accordingly, consumers purchase and own luxury products because of their higher quality (Vigneron and Johnson 1999). Indeed, there are numerous empirical studies that indicate perceived quality is the most important determinant of the perceived value (Zeithaml 1988; Harris and Goode 2004). Thus, the model proposed in this study suggests that four dimensions of perceived values of luxury products are highly correlated to consumers' quality perceptions, which is hypothesized as below:

H1: Consumers' perceived quality in luxury products influences positively perceived conspicuous value.

H2: Consumers' perceived quality in luxury products influences positively perceived status value.

H3: Consumers' perceived quality in luxury products influences positively perceived hedonic value.

H4: Consumers' perceived quality in luxury products influences perceived positively utilitarian value.

\subsection{Value Dimensions}

Defining perceived value only on customer perceived price is a vital but inadequate conceptualization because price is highly interrelated and frequently used with the concepts of benefits and sacrifice (Boksberger and Melsen 2011). So, consumer perceived value is commonly defined as "a ratio or trade- 
off of total benefits received to total sacrifices" (Patterson and Spreng 1997). Conceptualized by Zeithaml (1988) and Cronin et al. (2000), perceived value is the consumer's overall assessment of the utility of a product based on perceptions of what is received and what is given. Since then, perceived value research has become an interdisciplinary area involving psychology, sociology, economic and business concepts. In this research, the term "perceived value" refers to a judgment of preference by consumers (Grewal et al. 1998). For more details, perceived value is the worth that a product or service has in the mind of the consumer and affects his or her willingness to pay for the product/service. For the majority, consumers are not able to aware of the true cost of service or production for the products they buy; therefore, they simply have an internal feeling for how much certain products are worth to them. Analyzing consumer choice to buy or not to buy, to pick out between two products, and to select one brand or another, Vegneron and Johnson (1999) provided the perspective on aspects of luxury by perceived values, contingent on a particular socioeconomic framework. However, the value of the luxury products consumers perceive have changed as a result of globalization and modernization. Also, there are some difference towards perceived values of luxury products based on local cultures. Therefore, this study examine four common perceived values of luxury products, including conspicuous value, status value, hedonic value, and utilitarian value.

\subsection{Value: Conspicuous}

Consumers forged their own identity by the products they use (Belk, Kenneth and Robert 1982) and they use price indication as the surrogate for degree of prestige (Groth and McDaniel 1993). Moreover, consumer perceived higher prices as a characteristic manifestation of greater quality (Rao and Monroe 1989), which contribute to the luxury products' desire. As a result, consumers, not only the rich but all social classes too, spend a lot on products or services for the specific purpose of publicly displaying their wealth and their social status (Veblen 1965). Also, luxury products are preferred for many consumers in developing their social value (Shukla 2011). Thus, the luxury products could dominate the market for conspicuous consumers who utilize them to show their wealth, power, and social status. The consumer behavior is directly or indirectly affected by social factors, such as family, social status, and reference groups. Based on Bourne's study (1957), researchers worked and concluded that the reference groups have an influence on the conspicuousness of a product (Bearden and Etzel 1982). Conspicuous value of luxury products among the public can fulfill the need of their consumers to impress others and show their "success". Evenly, there are 
people who are willing to buy counterfeit products rather than buying the same quality product but not branded in order to satisfy their needs of conspicuousness (Grossman and Shapiro 1988).

H5: Perception of conspicuous value has a positive impact on social media wordof-mouth.

H6: Perception of conspicuous value has a positive impact on purchase intentions for luxury product.

\subsection{Value: Status}

Dittmar's research (1994) on the motives for luxury consumption reveals that people usually purchase and use luxury products to impress others. As many consumers' perceptions, luxury products could give them a sense of belonging to an exclusive group of the minority who bear the expense of these pricey items (O'Cass and McEwen 2004). As some research, status value of luxury products is the key reason of consumers' decision on purchasing luxury products. Thus, advertising and marketing campaigns from the world's leading luxury brands and retailers often use images of toptier social class to motivate consumers' desire to obtain status through material possessions. Although consumers belonging to western developed countries have a much higher focus on their actual self-concept (Shukla 2010), consumers' luxury purchase intentions in eastern emerging markets are significantly affected by status value (Shukla 2012). Nowadays, people tend to prefer connections with the others through social network to offline. Whether or not there are Vietnamese consumers who use social network as a method to show their "upscale" social status through luxury products they possess?

H7: Perception of status value has a positive impact on social media word-of-mouth.

H8: Perception of status value has a positive impact on purchase intentions for luxury product.

\subsection{Value: Hedonic}

Associated with growth of society, people's demand for products is increasing and diverse. The needs of people are no longer just for consumer products, but also products of enjoyment. Their choice might be driven by non-cognitive and unconscious motives (Dichter 2002). Some products are known to have sentimental value beyond their functional utility (Sheth, Bruce and Barbara 1991a). Hedonic consumption is defined as the "consumer behavior that relates to the multisensory, fantasy, and emotive aspects of product usage experience" (Hirschman and Holbrook 1982, p. 92). It suggests that the exhilarating experiences a consumer has when using those products will 
drive his or her purchases because hedonic products are involved with hopes, dreams, and desires. Luxury products create favorable environment for the hedonic consumption (Vigneron and Johnson 2004) due to their subjective intangible benefits, important parts of perceived utility as a result of purchase and consumption of luxury products (Vigneron and Johnson 1999). Recent research shows that the effects of hedonism on luxury purchase intentions are more in western developed markets than eastern emerging markets (Tse, Russell and Nan 1989; Shukla 2012).

H9: Perception of hedonic value has a positive impact on social media wordof-mouth.

H10: Perception of hedonic value has a positive impact on purchase intentions for luxury product.

\subsection{Value: Utilitarian}

In terms of the shopping motive, consumers choosing among products are driven by both hedonic and utilitarian considerations (Grewal et al. 2003). Obviously, while hedonic consumptions give consumers more experiential, exciting, fun, and pleasant, utilitarian consumptions are mainly instrumental and functional (Strahilevitz and Myers 1998). As Overby and Lee’s study (2006), "utilitarian value is defined as an overall assessment of functional benefits and sacrifices of functional benefits and sacrifices" (p.1161). Utilitarian consumers' shopping is generally achieved by the urge of particular consumption demands. Through practical information and understanding, consumers have gained the confidence and attitude towards products, which influences on their behavior, belief, and judgment on products selected. Many people still believe that price and quality of products has existed a positive relationship (Rao and Monroe 1989), which is one of the reasons for high price of luxury products. If consumers perceived a branded product being more expensive than normal standards, that product would be more value in the consumers' mind (Brucks, Valarie and Gillian 2000). Understanding this market sentiment, luxury brands charge higher prices than regularly purchased brands (Shukla 2012). The authors of research on signaling status with luxury goods demonstrated that price-quality relationship is usually used to create and present the users' image (Hung et al. 2011). Based on increasingly growth of social network, social media word-of-mouth has gradually become the main channel of communication to promote the consumers' upscale image with others.

H11: Perception of utilitarian value has a positive impact on social media wordof-mouth.

H12: Perception of utilitarian value has a positive impact on purchase intentions 
for luxury product.

\subsection{Social Media Word-of-Mouth and Purchase Intentions for Luxury Products}

Traditionally, the term "luxury" would be assigned to items that were both uncommon and scarce and limited to the glamorous elite (Nueno and Quelch 1998). Nowadays, luxury goods have been democratized into commodities anyone can own, but not lose its identity. Although luxury goods are defined as nonessential but more enjoyable items, consumers' perceptions of luxury items are not consistent across individuals, primarily because luxury is a subjective concept (Phau and Prendergast 2000) depending on consumers' hobbies, cultures, as well as perceptions of indulgent value, functional value and price. Vietnamese people's definition of luxury is quite different with the other markets, as it is led by premium price and quality rather than exclusiveness or uniqueness (Lee 2012). Social media have changed consumers and marketers' communicate (Nambisan and Baron 2007). Social media websites attract millions of users, many of whom integrate the sites into their daily lives and business practices (Okazaki 2009). According to recent research, more and more organizations employ social media to share, co-create, discuss, and modify user-generated content (Kietzmann et al. 2011). Social media have become an increasingly important communication channel for firms and consumers. Due to its immediacy, social media is an ideal unparalleled platform for consumers to share their product experiences and opinions, through word-of-mouth (Zhang, $X$ in and $Y u$ 2012), which refers to the spreading of online reviews, arguments, and recommendations on products or service providers based on personal experience with specific products or service with a view to generating persuasive effects on the targeted audiences (Shih, Kee and TC 2013). Taking into account that consumers usually ask for advices from relatives, friends, and peers. Besides, consumers also look at the comments about products/ services on social networks prior to purchasing an item. Consumers' perception of products and services would be obviously impacted by social media word-of-mouth. Consumers usually find out information related to products they intend to purchase in order to mitigate perceived risks (Srinivasan and Ratchford 1991).

Certainly, luxury products are no exception. Word of mouth is one of information channels that consumers are easily to approach information. Many previous research have revealed the influences of offline and online word of mouth on consumer purchasing behaviors (Lau and Ng 2001; Nabi and Hendriks 2003).

H13: The social media word-of-mouth influences positively purchase intentions for luxury products. 


\section{〈Figure 1〉 Conceptual Model of Research}

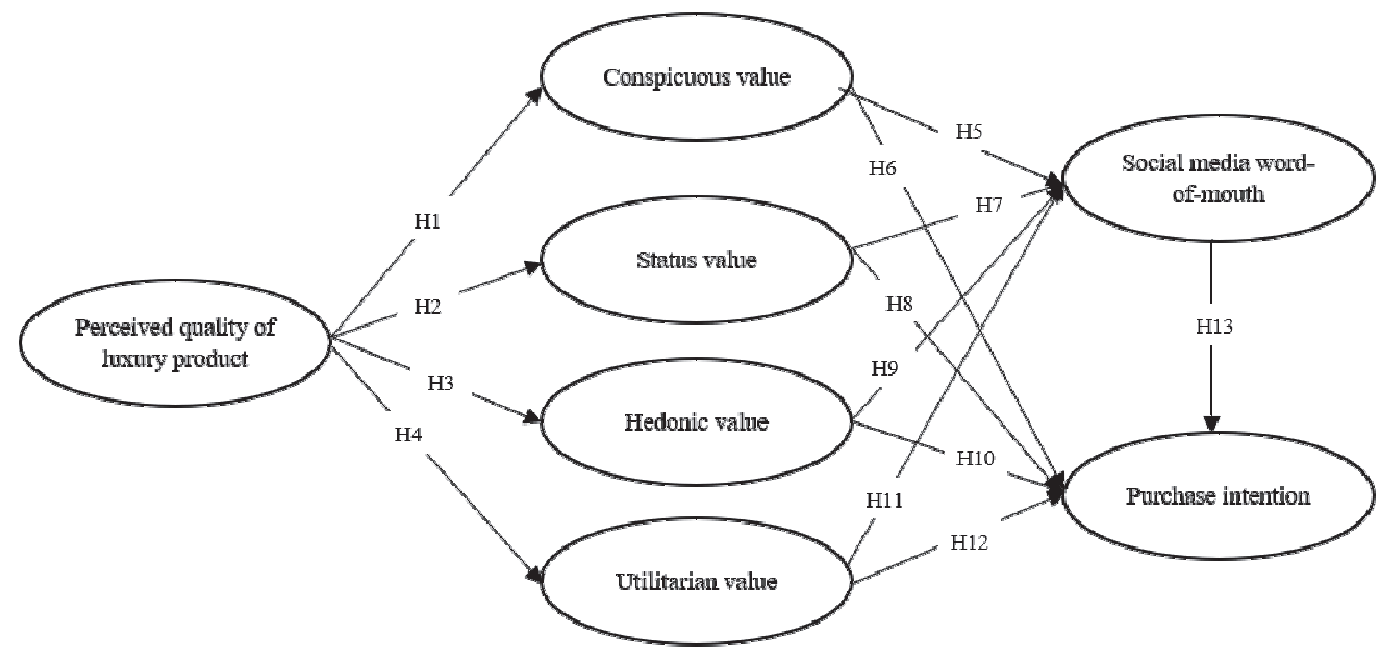

\section{Methodology}

\subsection{Data Collection and Sample Characteristics}

Quantitative research is conducted with survey data which consists of a series of bilingual questionnaire related to the study concepts. The questionnaire was initially prepared in English, then translated into Vietnamese and back translated into English. The original and back-translated English questionnaires were compared and modified if necessary to eliminate discrepancies between the two versions to verify the accuracy of the translation. Data is mainly collected in two biggest cities of Vietnam: Hanoi and Ho Chi Minh City. Respondents are adults at least 18 years old who are living or working at there. The mail survey is public and sent to potential respondents' company who are recruited by a Vietnamese market research company. After filtering and cleaning data collected, a final sample of 287. Sample descriptions (Table 1) showed that female respondents accounted for $44.25 \%$ of the sample, while male respondents represented slightly greater with $55.75 \%$. Slightly over three-fourths of respondents are young people (76.3\%) with age less than 30 years old. In terms of educational level, $72.13 \%$ of the sample had a bachelor degree. Annual income of respondents with less than $\$ 2,000$ accounted for $35.19 \%$, meanwhile $35.54 \%$ of respondents had income between $\$ 2,000$ and $\$ 6,000$ and rest of respondents, accounted for $29.27 \%$ had annual income above \$6,000.

\subsection{Measurement and Validation}

Measures for perceived quality on luxury 
〈Table 1〉 Respondents' Socio-Demographic Characteristics

\begin{tabular}{|c|c|c|c|}
\hline Variable & Group & Frequency & Percent \\
\hline \multirow[t]{4}{*}{ Age } & $<30$ years of age & 219 & $76.30 \%$ \\
\hline & $30-50$ & 65 & $22.65 \%$ \\
\hline & $50-65$ & 2 & $70 \%$ \\
\hline & $>65$ years of age & 1 & $35 \%$ \\
\hline \multirow[t]{2}{*}{ Gender } & Male & 160 & $55.75 \%$ \\
\hline & Female & 127 & $44.25 \%$ \\
\hline \multirow[t]{7}{*}{ Income } & $<\$ 2,000$ & 101 & $35.19 \%$ \\
\hline & $\$ 2,000-\$ 6,000$ & 102 & $35.54 \%$ \\
\hline & $\$ 6,000-\$ 10,000$ & 31 & $180 \%$ \\
\hline & $\$ 10,000-\$ 20,000$ & 31 & $180 \%$ \\
\hline & $\$ 20,000-\$ 40,000$ & 12 & $4.18 \%$ \\
\hline & $\$ 40,000-\$ 60,000$ & 4 & $1.39 \%$ \\
\hline & $>\$ 60,000$ & 6 & $2.09 \%$ \\
\hline \multirow[t]{9}{*}{ Education } & Less than high school degree or equivalent & 1 & $35 \%$ \\
\hline & High school diploma or equivalent & 9 & $3.14 \%$ \\
\hline & Trade/technical/vocational school (2 years) & 9 & $3.14 \%$ \\
\hline & Some college but no degree & 8 & $2.79 \%$ \\
\hline & Associate degree & 30 & $145 \%$ \\
\hline & Bachelor degree & 207 & $72.13 \%$ \\
\hline & Graduate degree & 19 & $6.62 \%$ \\
\hline & Professional degree (MD, JD, etc.) & 1 & $0.35 \%$ \\
\hline & Others & 3 & $1.05 \%$ \\
\hline \multicolumn{2}{|r|}{ Total } & 287 & $100 \%$ \\
\hline
\end{tabular}

product, perceived values (including conspicuous value, status value, hedonic value, and utilitarian value), social media word-of-mouth, and purchase intentions for luxury products were rated on a 5-point Likert scale ranging from strongly disagree to strongly agree. Perceived quality on luxury product was measured by Dodds, Kent and Dhruv's (1991) scale measuring 6 dimensions of perceived quality. Shukla's (2012) modified perceived value scale, which demonstrates good internal consistency reliability and validity, were used to measure consumer's perception of value on luxury products. Kuang et al.'s (2011) purchase intention scale and Jorge et al.'s (2013) social media word-ofmouth scale were used to measure purchase intentions for luxury products and social media word-of-mouth. The reliability checks were conducted to test the inter-item correlations of the measurement scales with the acceptance 
〈Table 2〉 Reliability and Validity Tests

\begin{tabular}{|c|c|c|c|c|c|c|c|}
\hline & Indicator & Loading & $t$-value & $\mathrm{SMC}$ & Cronbach-a & AVE & C.R \\
\hline \multirow{6}{*}{$\begin{array}{l}\text { Perceived } \\
\text { Quality }\end{array}$} & PQ 1 & 1.00 & - & .59 & \multirow[t]{6}{*}{.89} & \multirow[t]{6}{*}{.55} & \multirow[t]{6}{*}{.88} \\
\hline & $\mathrm{PQ} 2$ & 1.00 & 15.69 & .59 & & & \\
\hline & PQ 3 & 1.07 & 12.90 & .63 & & & \\
\hline & $\mathrm{PQ} 4$ & 1.09 & 13.19 & .66 & & & \\
\hline & $\mathrm{PQ} 5$ & .91 & 11.18 & .46 & & & \\
\hline & $\mathrm{PQ} 6$ & .78 & 10.11 & .38 & & & \\
\hline \multirow{4}{*}{$\begin{array}{l}\text { Conspicuous } \\
\text { Value }\end{array}$} & CV 1 & 1.00 & - & .66 & \multirow[t]{4}{*}{.84} & \multirow[t]{4}{*}{.57} & \multirow[t]{4}{*}{.82} \\
\hline & CV 2 & 1.01 & 13.54 & .60 & & & \\
\hline & CV 3 & .91 & 13.26 & .58 & & & \\
\hline & CV 4 & .75 & 11.17 & .42 & & & \\
\hline \multirow[t]{2}{*}{ Status Value } & SV 1 & 1.00 & 13.27 & .65 & \multirow[t]{2}{*}{.81} & \multirow[t]{2}{*}{.68} & \multirow[t]{2}{*}{.80} \\
\hline & SV 2 & 1.00 & - & .71 & & & \\
\hline \multirow[t]{3}{*}{ Hedonic Value } & HV 1 & 1.00 & - & .57 & \multirow[t]{3}{*}{.86} & \multirow[t]{3}{*}{.67} & \multirow[t]{3}{*}{.83} \\
\hline & HV 2 & 1.20 & 14.43 & .82 & & & \\
\hline & HV 3 & 1.07 & 13.41 & .64 & & & \\
\hline \multirow{3}{*}{$\begin{array}{c}\text { Price-Quality } \\
\text { Perceptions }\end{array}$} & PQP 1 & 1.00 & - & .63 & \multirow[t]{3}{*}{.74} & \multirow[t]{3}{*}{.50} & \multirow[t]{3}{*}{.73} \\
\hline & $\mathrm{PQP} 2$ & .97 & 11.43 & .51 & & & \\
\hline & PQP 3 & .79 & 9.64 & .37 & & & \\
\hline \multirow{3}{*}{$\begin{array}{l}\text { Social Media } \\
\text { Word-of-mouth }\end{array}$} & SWOM 1 & 1.00 & - & .46 & \multirow[t]{3}{*}{.77} & \multirow[t]{3}{*}{.55} & \multirow[t]{3}{*}{.77} \\
\hline & SWOM 2 & 1.02 & 10.67 & .68 & & & \\
\hline & SWOM 3 & .83 & 9.95 & .50 & & & \\
\hline \multirow{2}{*}{$\begin{array}{l}\text { Purchase } \\
\text { Intentions }\end{array}$} & PI 1 & 1.00 & - & .72 & \multirow[t]{2}{*}{.80} & \multirow[t]{2}{*}{.67} & \multirow[t]{2}{*}{.80} \\
\hline & P1 2 & .99 & 1.03 & .62 & & & \\
\hline Goodness-of & $\therefore x_{205}^{2}=3$ & $\begin{array}{r}551, p<.0 \\
\text { TLI }=.9\end{array}$ & $\begin{array}{l}\mathrm{GFI}=.90 \\
\mathrm{RMR}=.\end{array}$ & $\begin{array}{l}F I=.904 \\
\text { RMSEA }\end{array}$ & $\begin{array}{l}\mathrm{CFI}=.958 ; \mathrm{R} \\
.049\end{array}$ & $=.881 ;$ & 959; \\
\hline
\end{tabular}

level of Cronbach's coefficient alpha should be at least .7 (Kline 1998). The Cronbach's alpha of variables was over .7 that means all the data collected were reliable (Table 2).

\subsection{Analysis and Results}

All the hypotheses were tested by analyzing the structural model that shows the relationships of variables after confirmatory factor analysis (CFA). After modifying the measurement model, the overall goodness of fit for this model has a satisfactory model fit $\left(\chi_{205}^{2}=\right.$ 344.55, $p<.00 ; \mathrm{GFI}=.91 ; \mathrm{NFI}=.90 ; \mathrm{CFI}=.96$; $\mathrm{RFI}=.88 ; \mathrm{IFI}=.96 ; \mathrm{TLI}=.95 ; \mathrm{RMR}=.05$; RMSEA $=.05)$. The results of the measurement model are presented in Table 2 and Table 3.

For the perception of value, the predecessor 
〈Table 3〉 Construct Means, Standard Deviations, and Correlations

\begin{tabular}{|c|r|r|r|r|r|r|c|}
\hline & $\mathrm{PQ}$ & $\mathrm{CV}$ & $\mathrm{SV}$ & $\mathrm{HV}$ & $\mathrm{PQP}$ & SWOM & PI \\
\hline $\mathrm{PI}$ & 1.00 & & & & & & \\
\hline $\mathrm{UV}$ & .55 & 1.00 & & & & & \\
\hline HV & .34 & .48 & 1.00 & & & & \\
\hline ATT & .21 & .31 & .51 & 1.00 & & & \\
\hline AUP & .57 & .44 & .50 & .42 & 1.00 & & \\
\hline IUP & .44 & .43 & .38 & .37 & .44 & 1.00 & \\
\hline CI & .19 & .28 & .46 & .36 & .36 & .37 & 1.00 \\
\hline Means & 3.69 & 3.49 & 2.91 & 2.89 & 3.29 & 3.50 & 3.00 \\
\hline S. D. & .81 & .89 & .95 & .99 & .84 & .84 & .93 \\
\hline
\end{tabular}

PQ: Perceived Quality, CV: Conspicuous Value, SV: Status Value, HV: Hedonism

PQP: Price-Quality Perceptions, SWOM: Social media Word-of-mouth, PI: Purchase Intentions

〈Table 4〉 Structural Models Results

\begin{tabular}{|l|c|c|}
\hline \multicolumn{1}{|c|}{ Structural Path } & Coefficient & t-Value \\
\hline H1: Perceived Quality $\rightarrow$ Conspicuous Value & .74 & $8.98^{* * *}$ \\
\hline H2: Perceived Quality $\rightarrow$ Status Value & .46 & $6.02^{* * *}$ \\
\hline H3: Perceived Quality $\rightarrow$ Hedonism & .27 & $3.53^{* * *}$ \\
\hline H4: Perceived Quality $\rightarrow$ Price-Quality Perceptions & .77 & $9.95^{* * *}$ \\
\hline H5: Conspicuous Value $\rightarrow$ Social media Word-of-mouth & .24 & $3.19^{* *}$ \\
\hline H6 Conspicuous Value $\rightarrow$ Purchase Intentions & -.11 & -1.34 \\
\hline H7: Status Value $\rightarrow$ Social media Word-of-mouth & -.07 & -.66 \\
\hline H8: Status Value $\rightarrow$ Purchase Intentions & .48 & $4.08^{* * *}$ \\
\hline H9: Hedonic Value $\rightarrow$ Social media Word-of-mouth & .17 & $2.19^{*}$ \\
\hline H10: Hedonic Value $\rightarrow$ Purchase Intentions & .09 & 1.05 \\
\hline H11: Utilitarian Value $\rightarrow$ Social media Word-of-mouth & .40 & $3.86^{* * *}$ \\
\hline H12: Utilitarian Value $\rightarrow$ Purchase Intentions & -.07 & -.60 \\
\hline H13: Social media Word-of-mouth $\rightarrow$ Purchase Intentions & .33 & $3.26^{* *}$ \\
\hline Goodness-of-fit $: \chi^{2}$ 209 $=364.01, p<.00 ;$ GFI=.90; NFI=.90; RFI=.88; IFI=.95; TLI=.94; CFI=.95, \\
\hline \multicolumn{2}{|c|}{ RMR=.07; RMSEA =.05 } \\
\hline
\end{tabular}

**** $p<.001,{ }^{* *} p<.01, * p<.05$

of how Vietnamese consumers perceived the quality of luxury product has a significant positive impact on their perceptions of value of luxury products $(\mathrm{p}<.001)$. In more detailed, hypotheses from $\mathrm{H} 1$ to $\mathrm{H} 4$ asserted the influences of perceived quality of luxury products on Vietnamese consumers' perceptions of their conspicuous, status, hedonic, and utilitarian 
value. As indicated in Table 4, results of the analysis revealed that conspicuous value $(\beta=$ .74, $\mathrm{p}<.001)$, status value $(\beta=.46, \mathrm{p}<.001)$, hedonic value $(\beta=.27, p<.001)$, and utilitarian value $(\beta=.77, p<.001)$ had significant relationships with consumers' perception of quality of luxury products. Consequently, hypotheses 1, 2, 3, and 4 were supported. Focusing on social media word-of-mouth, it was hypothesized that perceived values of luxury products will impact on social media word-of-mouth. Support were observed for H5, H9, and H11 as the relationship between conspicuous value $(\beta=.24, p<.01)$, hedonic value $(\beta=.17, p<.05)$, and utilitarian value $(\beta=.40, p<.001)$ with social media wordof-mouth were found to be significant across the pooled data. However, social media wordof-mouth was not affected by status value of luxury products $(\beta=-.07, t-$ Value $=-.66)$. Conversely, status value had a considerable influence on Vietnamese consumers' purchase intentions for luxury products $(\beta=.48, \mathrm{p}<$ .001). In the meanwhile, their luxury purchase intentions are not impacted by conspicuous value, hedonic value, and utilitarian value of luxury products. Consequently, H8 was supported while H6, 10, and 12 were rejected. With regards to H13, social media word-of-mouth had a significant positive effect on consumer luxury purchase intentions $(\beta=.33, p<.01)$. It means the hypothesis H13 was supported.

\section{Discussions and Implications}

The main purpose of this research was to carry out a systematic or formal inquiry to discover and examine the factors impacting on Vietnamese consumer luxury purchase intentions. Based on Sheth's theory on consumption value (1991b), this research examines the impact of individual perceptions on consumers' attitudes towards luxury products, which have taken effect upon their behaviors and intentions to purchase luxury products. There are some studies on consumers' value perceptions of luxury in recent years (Wiedmann et al. 2007; Berthon, Leyland, Michael and Jean 2009). Associated with the dramatic growth of developing markets, research are paying more attention to cultural differences of consumers' value perception regarding luxury goods (Tynan, Sally and Celine 2010; Shukla 2012). This paper empirically examines the Vietnamese consumers' perceptions of luxury products and their effects on intentions to purchase luxury products. The finding reveals that Vietnamese participants who intended to buy luxury products in the near future considered only status value. However, their luxury purchase intentions are not impacted by conspicuous, hedonic, and utilitarian values of luxury products. Because cultural variables were not included in our questions, some of Shukla's (2012) findings were not supported in Vietnamese context. 
In accordance to the boom of digital media, social media is increasingly showing its effects in brands' campaigns because it is getting invaluable assistance from intelligent devices in Vietnam, especially in mobile. The number of mobile users have increasingly accessed to social network every days from their phones due to their ability to interact, to spread, and to share information. However, there is much academic and business practical debate about the influence of online word-of-mouths on purchase intentions (Jalilvand and Samiei 2012; Mikalef, Michail and Colin 2013). This research has replicated the approached taken to studying online word-of-mouth with social media platform. The results indicate Vietnamese consumers' luxury purchase intentions are directly affected by social media word-of-mouth. However, an interesting finding is revealed that while purchase intentions for luxury products are only impacted by their status value, meanwhile their conspicuous value, hedonic value, and utilitarian value have influences on consumers' social media word-of-mouths.

While nine over thirteen proposed hypotheses were supported, this study's results confirm that Vietnamese consumers' purchase behavior towards purchasing luxury products has a direct or indirect relationship with their perceived quality and perceived values of luxury, as well as social media word-of-mouth. With the express purpose of initially studying factors impacting on purchase intentions for luxury products, the results of this research will directly suggest to luxury retailers the influential factors of Vietnamese consumers' decision on purchasing luxury products and their relationships. Retailers will have a comprehensive view of Vietnamese people's purchase intentions for luxury products and could map out the strategies for gaining consumers' sensory perceptions of quality and values of luxury products, especially status value which directly impact on purchase intentions for luxury products. Additionally, luxury retailers could be keen to properly exploit the strength of social media word-of-mouth in order to boost sales of luxury products.

\section{Limitations}

Obviously, many Vietnamese customers own luxury products to demonstrate their power or their social class, while others buy luxury products because of their quality, not just for appearance. The essence of issue could be explained by geographical lines. In Hanoi what is most important is the brand, whereas in Ho Chi Minh City it's more about the functionality, says Truitt (2008). The future research should study on the consumers' different awareness of luxury products in accordance with geographic and local culture. Because this research was mainly conducted in two major cities, the findings may not represent the overall population in 
Vietnam. The further studies should re-examine these effect factors in other cities and measure how the local cultures impact on consumers' perceptions as well as purchases intentions. Future studies could also explore the mediate components of personal commitment to repurchase intentions for luxury products. Next, the research has just studied the indirectly influential factors, social media word-of-mouth, on purchase intentions for luxury products. The future research should measure the impact of other types of wordof-mouth, including offline word-of-mouth and online word-of-mouth in forums, blogs, and so on. Moreover, social media word-of-mouth can be both negative and positive, the future research should measure how negative and positive social media word-of-mouth influences consumer purchase behavior. While this study presented generally Vietnamese consumers' views on luxury products and the affective factors of luxury purchase intentions, the further researched may examine the difference in consumers' attitudes and behaviors between who have bought and/or used luxury products and who have not bought and used yet. Comparative studies will give marketers reasonable opportunities for segmenting the market and matching their product offering to each market segment.

〈Received October 1. 2017〉 〈Accepted January 28. 2018〉

\section{References}

Aaker, D. A. (1992). Managing brand equity: capitalizing on the value of a brand name. Journal of Marketing, 56(2), 125-128.

Agbonifoh, B. A., \& Elimimian, J. U. (1999). Attitudes of developing counties towards "country-of-origin" products in an era of multiple brands. Journal of International Consumer Marketing, 11(4), 97-116.

Bearden, W. O., \& Etzel, M. J. (1982). Reference group influence on product and brand purchase decisions. Journal of consumer research, 9(2), 183-194.

Belk, R. W., Bahn, K. D., \& Mayer, R. N. (1982). Developmental recognition of consumption symbolism. Journal of consumer research, 9(1), 4-17.

Berthon, P., Pitt, L., Parent, M., \& Berthon, J. P. (2009). Aesthetics and ephemerality: observing and preserving the luxury brand. California management review, 52(1), 4566.

Besanko, D., \& Braeutigam, R. R. (2005). Microeconomics. Hoboken.NJ: John Wiley and Sons.

Bian, Q., \& Forsythe, S. (2012). Purchase intention for luxury brands: A cross cultural comparison. Journal of Business Research, 65(10), 1443-1451.

Boksberger, P. E., \& Melsen, L. (2011). Perceived value: a critical examination of definitions, 
concepts and measures for the service industry. Journal of services marketing, 25(3), 229-240.

Bourne, F. S. (1957). Group influence in marketing and public relations. Some applications of behavioral research, 207255.

Brucks, M., Zeithaml, V. A., \& Naylor, G. (2000). Price and brand name as indicators of quality dimensions for consumer durables. Journal of the academy of marketing science, 28(3), 359-374.

Brun, A., \& Castelli, C. (2013). The nature of luxury: a consumer perspective. International Journal of Retail \& Distribution Management, 41(11/12), 823-847.

Cronin, J. J., Brady, M. K., \& Hult, G. T. M. (2000). Assessing the effects of quality, value, and customer satisfaction on consumer behavioral intentions in service environments. Journal of retailing, 76(2), 193-218.

D’arpizio, C., Levato, F., Zito, D., \& de Montgolfier, J. (2015). Luxury goods worldwide market study. Bain and Company.

Dichter, E. (1960). The strategy of desire. Transaction Publishers.

Diniz, C. (2014). The luxury market in Brazil: Market opportunities and potential. Springer. Dittmar, H. (1994). Material possessions as stereotypes: Material images of different socio-economic groups. Journal of Economic psychology, 15(4), 561-585.

Dodds, W. B., Monroe, K. B., \& Grewal, D.
(1991). Effects of price, brand, and store information on buyers' product evaluations. Journal of marketing research, 307-319.

Etzioni, A. (1968). The active society: a theory of societal and political processes (No. HM101. E89 1968.) New York: Free Press. Garfein, R. T. (1989). Cross-cultural perspectives on the dynamics of prestige. Journal of services marketing, 3(3), 17-24.

Goody, J. (2006). From misery to luxury. Social Science Information, 45(3), 341-348.

Gorrab, D., 2013. Global Luxury Goods Sales Exceed US \$318 Billion. Retrieved from Market Wired, 10-8.

Grewal, D., Iyer, G. R., Krishnan, R., \& Sharma, A. (2003). The Internet and the price - value - loyalty chain. Journal of Business Research, 56(5), 391-398.

Grewal, D., Monroe, K. B., \& Krishnan, R. (1998). The effects of price-comparison advertising on buyers' perceptions of acquisition value, transaction value, and behavioral intentions. The Journal of Marketing, 46-59.

Grossman, G. M., \& Shapiro, C. (1988). Foreign counterfeiting of status goods. The Quarterly Journal of Economics, 103(1), 79-100.

Groth, J. C., \& McDaniel, S. W. (1993). The exclusive value principle: the basis for prestige racing. Journal of Consumer Marketing, 10(1), 10-16.

Harris, L. C., \& Goode, M. M. (2004). The four levels of loyalty and the pivotal role 
of trust: a study of online service dynamics. Journal of retailing, 80(2), 139-158.

Heath, M. C. (2000). Hypersensitive responserelated death. In Programmed cell death in higher plants (pp. 77-90). Springer Netherlands.

Herche, J. (1992). A note on the predictive validity of the CETSCALE. Journal of the Academy of Marketing Science, 20(3), 261-264.

Hirschman, E. C., \& Holbrook, M. B. (1982). Hedonic consumption: emerging concepts, methods and propositions. The Journal of Marketing, 92-101.

Hung, K. P., Huiling Chen, A., Peng, N., Hackley, C., Amy Tiwsakul, R., \& Chou, C. L. (2011). Antecedents of luxury brand purchase intention. Journal of Product \& Brand Management, 20(6), 457-467.

Jalilvand, R. M., \& Samiei, N. (2012). The effect of electronic word of mouth on brand image and purchase intention: An empirical study in the automobile industry in Iran. Marketing Intelligence \& Planning, 30(4), 460-476.

Jin, B., \& Gu Suh, Y. (2005). Integrating effect of consumer perception factors in predicting private brand purchase in a Korean discount store context. Journal of Consumer Marketing, $22(2), 62-71$.

Kietzmann, J. H., Hermkens, K., McCarthy, I. P., \& Silvestre, B. S. (2011). Social media? Get serious! Understanding the functional building blocks of social media. Business horizons, 54(3), 241-251.

Kim, A. J., \& Ko, E. (2012). Do social media marketing activities enhance customer equity? An empirical study of luxury fashion brand. Journal of Business Research, 65(10), 1480-1486.

Kim, Y., \& Wingate, N. (2017). Narrow, powerful, and public: the influence of brand breadth in the luxury market. Journal of Brand Management, 1-14.

Kline, R. B. (2015). Principles and practice of structural equation modeling. Guilford publications.

Hung, K. P., Huiling Chen, A., Peng, N., Hackley, C., Amy Tiwsakul, R., \& Chou, C. L. (2011). Antecedents of luxury brand purchase intention. Journal of Product \& Brand Management, 20(6), 457-467.

Lau, G. T., \& Ng, S. (2001). Individual and situational factors influencing negative wordof-mouth behaviour. Canadian Journal of Administrative Sciences/Revue Canadienne des Sciences de l'Administration, 18(3), 163-178.

Lee, R. (2012). Luxury report: Vietnam a growth hot spot, Retrieved from Campaign Asia-Pacific, 12(2).

Lee, J., \& Nguyen, M. J. (2017). Product attributes and preference for foreign brands among Vietnamese consumers. Journal of Retailing and Consumer Services, 35, 7683. 
Mai, N. T. T., \& Tambyah, S. K. (2011). Antecedents and consequences of status consumption among urban vietnamese consumers. Organizations and Markets in Emerging Economies, 2(1).

Maruyama, M., \& Trung, L. V. (2009). High shopping frequency of Vietnamese consumers: theory and measurement. Applied Economics Letters, 16(4), 411-415.

Matthaes, R. (2006). The middle class has landed, Vietnam Investment Review, 20.

McCracken, G. (1990). Culture and consumer behaviour: An anthropological perspective. Journal of the Market Research Society, 32(1), 3 .

McDonald, H., Darbyshire, P., \& Jevons, C. (2000). Shop often, buy little: The Vietnamese reaction to supermarket retailing. Journal of Global Marketing, 13(4), 53-71.

Mikalef, P., Giannakos, M., \& Pateli, A. (2013). Shopping and word-of-mouth intentions on social media. Journal of theoretical and applied electronic commerce research, 8(1), 17-34.

Nabi, R. L., \& Hendriks, A. (2003). The persuasive effect of host and audience reaction shots in television talk shows. Journal of Communication, 53(3), 527-543.

Nambisan, S., \& Baron, R. A. (2007). Interactions in virtual customer environments: Implications for product support and customer relationship management. Journal of interactive marketing; 21(2), 42-62.
Neate, R., 2013. Recession bypasses market for luxury goods. The Guardian, 2(15).

Nueno, J. L., \& Quelch, J. A. (1998). The mass marketing of luxury. Business Horizons, 41(6), 61-68.

O'cass, A., \& McEwen, H. (2004). Exploring consumer status and conspicuous consumption. Journal of consumer behaviour, 4(1), 2539.

Okazaki, S. (2009). The Tactical Use of Mobile Marketing: How Adolescents9 Social Networking Can Best Shape Brand Extensions. Journal of Advertising Research, 49(1), 12-26.

Overby, J. W., \& Lee, E. J. (2006). The effects of utilitarian and hedonic online shopping value on consumer preference and intentions. Journal of Business research, 59(10), 11601166.

Patterson, P. G., \& Spreng, R. A. (1997). Modelling the relationship between perceived value, satisfaction and repurchase intentions in a business-to-business, services context: an empirical examination. International Journal of service Industry management, 8(5), 414-434.

Petty, R. E., \& Cacioppo, J. T. (1986). Message elaboration versus peripheral cues. In Communication and Persuasion(pp. 141172). Springer, New York, NY.

Phau, I., \& Prendergast, G. (2000). Consuming luxury brands: the relevance of the 'rarity principle. The Journal of Brand Management, 
8(2), 122-138.

Rao, A. R., \& Monroe, K. B. (1989). The effect of price, brand name, and store name on buyers' perceptions of product quality: An integrative review. Journal of marketing Research, 351-357.

Roux, E. (1995). Consumer evaluation of luxury brand extensions. In: EMAC Conference, May, ESSEC, Paris. 1971-1980.

Sabiote, C. M., Frías, D. M., \& Castañeda, J. A. (2013). The moderating effect of culture on overall perceived value in the online purchasing process. Service Business, 7(1), 83-102.

Sashi, C. M. (2012). Customer engagement, buyer-seller relationships, and social media. Management decision, 50(2), 253-272.

Sheth, J. N., Newman, B. I., \& Gross, B. L. (1991a). Consumption values and market choices: Theory and applications. Cincinnati, $\mathrm{OH}$ : South-Western Pub.

Sheth, J. N., Newman, B. I., \& Gross, B. L. (1991b). Why we buy what we buy: A theory of consumption values. Journal of business research, 22(2), 159-170.

Shih, H. P., Lai, K. H., \& Cheng, T. C. E. (2013). Informational and relational influences on electronic word of mouth: An empirical study of an online consumer discussion forum. International Journal of Electronic Commerce, 17(4), 137-166.

Shukla, P. (2010). Status consumption in crossnational context: Socio-psychological, brand and situational antecedents. International Marketing Review, 27(1), 108-129.

Shukla, P. (2011). Impact of interpersonal influences, brand origin and brand image on luxury purchase intentions: Measuring interfunctional interactions and a crossnational comparison. Journal of world business, 46(2), 242-252.

Shukla, P. (2012). The influence of value perceptions on luxury purchase intentions in developed and emerging markets. International Marketing Review, 29(6), 574-596.

Shultz, C. J. (1994). Balancing policy, consumer desire and corporate interests: considerations for market entry in Vietnam. The Columbia Journal of World Business, 29(4), 42-52.

Srinivasan, N., \& Ratchford, B. T. (1991). An empirical test of a model of external search for automobiles. Journal of Consumer research, 18(2), 233-242.

Strahilevitz, M., \& Myers, J. G. (1998). Donations to charity as purchase incentives: How well they work may depend on what you are trying to sell. Journal of consumer research, 24(4), 434-446.

Sweeney, J. C., \& Soutar, G. N. (2001). Consumer perceived value: The development of a multiple item scale. Journal of retailing, 77(2), 203-220.

Teas, R. K., \& Agarwal, S. (2000). The effects of extrinsic product cues on consumers' perceptions of quality, sacrifice, and value. 
Journal of the Academy of marketing Science, 28(2), 278-290.

Truc, N. T. T., Nam, T. S., Ngan, N. V. C., \& Bentzen, J. (2016). Factors Influencing the Adoption of Small-scale Biogas Digesters in Developing Countries - Empirical Evidence from Vietnam. International Business Research, 10(2), 1.

Truitt, A. (2008). On the back of a motorbike: Middle-class mobility in Ho Chi Minh City, Vietnam. American Ethnologist, 35(1), 3-19.

Tse, D. K., Belk, R. W., \& Zhou, N. (1989). Becoming a consumer society: A longitudinal and cross-cultural content analysis of print ads from Hong Kong, the People's Republic of China, and Taiwan. Journal of consumer research, 15(4), 457-472.

Tynan, C., McKechnie, S., \& Chhuon, C. (2010). Co-creating value for luxury brands. Journal of Business Research, 63(11), 1156-1163.

Twitchell, J. B. (2003). Living it up: America's love affair with luxury. Simon and Schuster. Veblen, T. (1965). The theory of the leisure class. 1899. AM Kelley, bookseller.

Vigneron, F., \& Johnson, L. W. (1999). A review and a conceptual framework of prestigeseeking consumer behavior. Academy of Marketing Science Review, 1999, 1.

Vigneron, F. and L. W. Johnson, 2004. Measuring perceptions of brand luxury. In Advances in Luxury Brand Management Palgrave Macmillan, Cham, 199-234.

Wegener, B. (1992). Concepts and measurement of prestige. Annual review of sociology, 18(1), 253-280.

Wiedmann, K. P., Hennigs, N., \& Siebels, A. (2007). Measuring consumers' luxury value perception: a cross-cultural framework. Academy of Marketing Science Review, 1. Wilcox, K., Kim, H. M., \& Sen, S. (2009). Why do consumers buy counterfeit luxury brands?. Journal of marketing research, 46(2), 247-259.

Woodruff, R. B. (1997). Customer value: the next source for competitive advantage. Journal of the academy of marketing science, 25(2), 139-153.

Zeithaml, V. A. (1988). Consumer perceptions of price, quality, and value: a means-end model and synthesis of evidence. The Journal of marketing, 2-22.

Zhang, Z., Li, X., \& Chen, Y. (2012). Deciphering word-of-mouth in social media: Textbased metrics of consumer reviews. ACM Transactions on Management Information Systems (TMIS), 3(1), 5.

Zhao, X. (2006). Consumer-perceived value of salon hair coloring: A cross-cultural comparison of Gen Y cohorts in China and the United States. 2243-2243. 